\title{
Biotechnological Approaches for Enhancing the Production of Vegetables - An Updated Overview
}

\author{
Ananya Kuanar', Ankita Pati ${ }^{1}$, Bibhudutta Pattnaik ${ }^{1}$, Ruchi Bhuyan ${ }^{2}$, Dattatreya Kar,"* \\ ${ }^{1}$ Centre for Biotechnology, Siksha O Anusandhan (Deemed to be University), Kalinga Nagar, Ghatikia, \\ Bhubaneswar, Odisha 751003, India \\ ${ }^{2}$ Department of Medical Research, Health Science, IMS \& SUM Hospital, Siksha O Anusandhan University, \\ Bhubaneswar, Odisha, India
}

Received August 30, 2021; Revised October 22, 2021; Accepted November 11, 2021

\section{Cite This Paper in the following Citation Styles}

(a): [1] Ananya Kuanar, Ankita Pati, Bibhudutta Pattnaik, Ruchi Bhuyan, Dattatreya Kar, "Biotechnological Approaches for Enhancing the Production of Vegetables - An Updated Overview, "Universal Journal of Agricultural Research, Vol. 9, No. 6, pp. 221 - 234, 2021. DOI: 10.13189/ujar.2021.090601.

(b): Ananya Kuanar, Ankita Pati, Bibhudutta Pattnaik, Ruchi Bhuyan, Dattatreya Kar (2021). Biotechnological Approaches for Enhancing the Production of Vegetables - An Updated Overview. Universal Journal of Agricultural Research, 9(6), 221 - 234. DOI: 10.13189/ujar.2021.090601.

Copyright $\bigcirc 2021$ by authors, all rights reserved. Authors agree that this article remains permanently open access under the terms of the Creative Commons Attribution License 4.0 International License

\begin{abstract}
Introduction: Biotechnology is an interdisciplinary field that deals specifically with many aspects of life with genetically modified medicine, food, global warming and energy production. Cultivation of low cost and disease-free crops as well as planting materials such as potatoes and bananas cannot be used for a long term, so through cryopreservation, the conservation of genetic resources is possible. Plant biotechnology has not only increased the scale of attributes that can be addressed but also accelerated the vegetable growing program. Using a biotechnology approach, traditional breeding thresholds such as relationship drag issue, wide cross sexual barrier, nutritional avoidance factor, etc. can be effectively and efficiently overcome. Study objects and methods: A basic and thorough overview of the literature surveyed to identify the application of biotechnology in the yield of vegetables was conducted till 2021. Results and discussion: Recent advances in the field of molecular biology such as genetic engineering (Cisgenesis, transgenic and intragenesis), DNA sequencing, cloning, molecular markers, in-vitro mutagenesis, etc., promote new meanings, modern dimensions and novel capabilities of decrepit biotechnology. It also provided a modern aspect of microbial interference in the agricultural practices, such as bio-control agents, bio-fertilizers and various microbiological products used in the current agricultural sector. Conclusion: Thus, the current biotechnological trends can have a striking impact on the advancement of
\end{abstract}

vegetable crops. The above review concludes with an emphasis on the revolution in the field of biotechnology that highlights advancement of horticulture science, which is accomplished with superior quality and higher productivity of vegetable crops.

Keywords Transgenic, Vegetable, Biotechnology, Molecular Marker, Genetically Modified

\section{Introduction}

From thousands of years, plant improvement has been practiced. Various processes like classical plant breeding, domestication and genetic engineering are altering the genome based on plant to increase individual traits being a crop. For crop improvement the most widely used methods are conventional breeding. These techniques must complement with biotechnological techniques in certain situations, whichever to raise their effectiveness or to fulfil an aim not viable by conventional techniques.

For generating huge scope of variation as well as utilizing the consequent innate variation for crop development, biotechnological method involving plant tissue culture provide a good technique. By usage of media with plant growth regulators, on the other hand, by 
in vitro mutagenesis, such variation should be induced in culture. Unexpectedly rich and novel changes can be induced through In vitro culture that successively gives a latest and major diversity in rejuvenated plants. The healing of hereditary transform in plants originated through tissue culture gives a chance to apply this diversity for growth of latest groups [1,2]. New diseases resistant varieties developed through tissue culture technique have created path for achieving a broad range of plants resistant to bacteria, virus, and fungi. Over the last decade, massive development has been made also a half in the multiplying of plants by tissue culture techniques along the only aim of developing a class with unique traits like disease resistance, higher productivity or character.

To introduce a useful genotype, traditional breeding proceeds lengthy times to begin while it needs various generations of crossbreeding and selection. Test tubes methods are clearly higher level to the traditional method. Biotechnology is visible as a broad title as long as the use of all biological action would exactly be labelled biotechnology. It would logically be practiced in food processing as deep accepted like bread production as well as brewing. Although, the transformation due to our interpretation made from the molecular methods root of the procedure of life has developed in the possible to use those methods for our demand. The present new-found skill and potential is generally labelled as biotechnology.

Here are two major approaches of biotechnology to fruit as well as vegetable yielding: Biotechnology as a support to traditional propagation plan and Biotechnology potential to move genes among individual organisms.

Morphological or Physiological traits are directed by chromosomal carried genes. The capability to observe the absence or presence of such genes in plants is animmense benefit to plant breeders. This is done through the use of characteristic DNA sequences, molecular markers or genes in question or fragments that are closely linked to the gene. Molecular biological techniques permit the monitoring of such markers in many independent individuals, for example the new varieties those arise as a result of crossing between two plant varieties. This is an extraordinary guide to the chosen techniques.

The specific genes might be joined to a crop variety in single track, keep away from all the crossbreeding that is commonly needed, giving a vital preserving of time and efforts are the ability to transfer genes. Moreover, these genes which are joined may not arise against a species especially sexually suitable along the crop in interrogation. Of course, traditional breeding is restricted to the initiation of genes against plants of the identical species or extremely close relatives. It is viable to introduce inside a crop plant distinct gene from distinct plants or whole animals, bacteria, or fungi by using the science of genetic engineering. Simplistically genes are prepared of two segments, the coding site that decide what the gene product obtain, as well as the promoter, a position of direction defining when, where and to what extent a gene is revealed. To supply genes with latest and helpful properties (recombinant DNA), coding sites and promoters from non-identical genes might be joined at one time in the laboratory. By the methods of plant genetic transformation, the above mentioned external or recombinant genes may then be changed inside crop plants. In the normal way the established genes incorporate within the plant genome and will be transferred to the progeny. In this manner it is viable to upgrade live traits and establish new features within a crop.

In this process of fruits and vegetables breeding, this whole portion investigates the use of biotechnology as well as their successive application in food processing. The primary mechanism and techniques of hereditary regulation, from the choice and separation of genes to safety cases like the steadiness of transgenes describe in tools of genetic engineering in plants section. Starting portions of the preceding sections then examines the scale of selected things for hereditary improvement, beginning with two parts on by what method biotechnology can upgrade feature and yield in fruit plus vegetable cultivation. The hereditary alteration of agronomic features in fruit crops like being immune to plant pests plus ecological stresses, herbicide resistance, growing productivity with fruit character expressed in genetic alterations of agricultural features in fruit crops parts. Genes elaborated in plant protection mechanisms part study in extra item at upgrading plant defences against pathogens. The features that influence ultimate product quality is discussed by a group of three sections. Genes choose for their part in improving post-harvest life part examined by what method biotechnology can use in expanding the post-harvest survival of fruit with vegetables, a progressively main matter given the problem of current produce chains. In order to enhance food behaviours like nutritional quality as well as sensory traits like colour with flavour were regulated by the application of molecular inheritance. Nutritional improvement of plant products can be improved by in plant food nutritional value.

Tomato was the first profit-oriented announced of a GM food by-product, the Flavr Savr tomato with expanded individual life of the mature fruit, and has eventually been a specific centre for investigation in this discipline. Profit-oriented progress with transgenic potato part observe present profit-oriented evolution besides transgenic potato while Cucurbits, eggplant, pepper, legumes and further vegetables part analysis tasks on a scope of many vegetables as well as fruit from melon with cucumber to cauliflower, cabbage, broccoli, including lettuce. Eventually, Consumer's point of view and Risk evaluation focuses on the total-major matters of consumer view and risk evaluation, with parts on these matters and recognizing GMOs in foods. 
Biotechnology is an interdisciplinary field that deals specifically with many aspects of life with genetically modified medicine, food global warming and energy production. Cultivation of low cost and disease-free crops as well as planting materials such as potatoes and bananas cannot be used for a long-term, so through cryopreservation, the conservation of genetic resources are possible. Plant biotechnology has not only increased the scale of attributes that can be addressed but also accelerated the vegetable growing program. Using a biotechnology approach, traditional breeding thresholds such as relationship drag issue, wide cross sexual barrier; nutritional avoidance factor, etc. can be effectively and efficiently overcome. Recent advances in the field of molecular biology such as genetic engineering (Cisgenesis, transgenic and intragenesis), DNA sequencing, cloning, molecular markers, in-vitro mutagenesis, etc., promote new meanings, modern dimensions and novel capabilities of decrepit biotechnology. It also provided a modern aspect of microbial interference in the agricultural practices, such as bio-control agents, bio-fertilizers and various microbiological products used in the current agricultural sector [3]. Thus, the current biotechnological trends can have a striking impact on the advancement of vegetable crops (Figure 1).

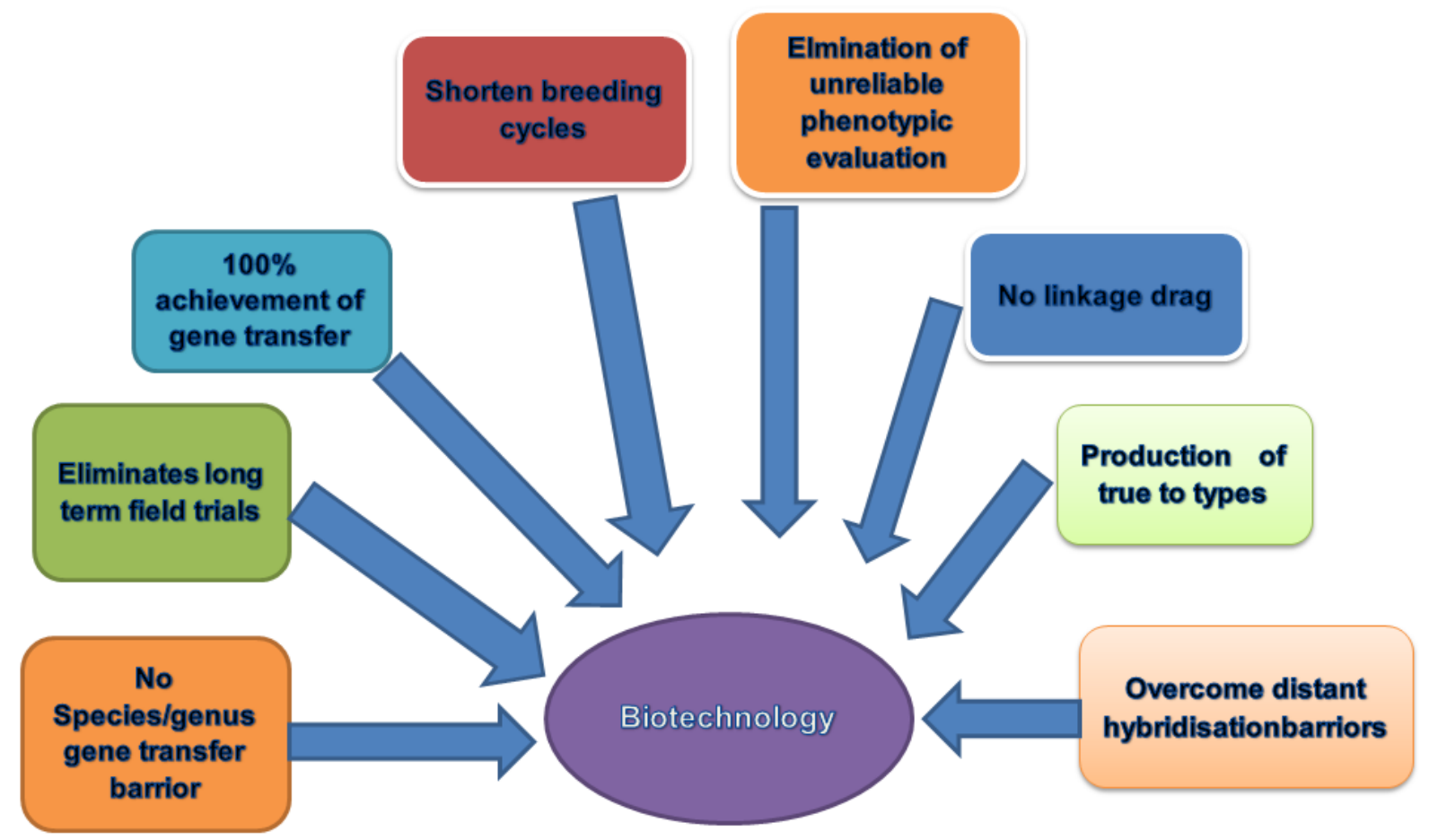

(Source: https://www.slideshare.net/AditikaSharma/advances-in-vegetable-improvement-through-biotechnological-approach.)

\section{Methodology for Data Collection and Screening}

A basic and thorough overview of the literature surveyed to identify the application of biotechnology in the yield of vegetables was conducted till 2021. Many offline and online data-bases were taken into consideration. The review articles and research papers published by various reputed publishers such as Elsevier, Springer and Taylor \& Francis imprints, Hindawi were considered as the data collection primary resource for this review article. Some online databases including NCBI, PubMed, Google Scholar, ProQuest, Scopus and EBSCO were also accessed using keywords relating to the topic for data mining. The paid articles were accessed through the Centre Library facility of Siksha $O$ Anusandhan University. The conference proceedings, magazines, WebPages and book chapters were also reviewed and accessed as the other sources of literature in order to maximize the information about the current bottlenecks, extent of research carried out and the potential utility of the topic, vegetable production through biotechnological research approaches. In this review the scope of biotechnological in vegetable production and its different approaches were discussed. The production of vegetable enhancement through biotechnological approaches is the main highlight of this review which will create a deep insight among the researchers about the updates and future research pertaining in the field of Horticulture Science and Biotechnology.

Figure 1. Need of biotechnological approaches for vegetable improvement. 


\section{Trending Approaches in the Field of Biotechnology}

To ameliorate the quantity and the quality of vegetables, different biotechnology methods and approaches have been utilized. The DNA based knowledge encouraged the scientists to isolate the targeted gene of interest and to transfer as well as to integrate it into the host species successful in isolating target gene of interest, its transfer and integration into the host species based on the knowledge of DNA. Plant biotechnology enables amelioration that is not possible with the traditional crossing was limited to related species alone but the amelioration in the field of plant biotechnology made it successful beyond the limit. Different highlighted methods and approaches have been discussed concisely below.

\subsection{Approach through Genetic Engineering}

The potential ameliorated quality and productivity in the vegetables or the horticultural crops can be achieved with the advanced approach of genetic engineering. The genetic engineering approach includes genetic material modification of a host plant through incorporation of a novel gene which enhances the immunity (disease free) or nutritive value or agronomic performances in the plant that are cultivated for commercial value in many countries, such plants are called as GM Plants or GM Crops [4]. The role of genetic engineering has been wide spread due to production of special characterized vegetable crops such as colours, aromas, flavours tastes, sizes, harvest durability, resistance against insects and pests etc. There are mainly two transgenic strategies for improvement of vegetable crops.

\subsubsection{Transgenic Approach for Biotic Stress Management}

Damage to plants occurs by biotic stress originated by additional living organisms like insects, parasites, viruses, bacteria, fungi, weeds etc. crop yield losses to a number of $40 \%$ despite of the application of insects, pathogens, fungicides, pesticides, herbicides, and weeds $[5,6]$. Globally preharvest wastes are evaluated to be $12 \%$ for weeds, $15 \%$ for pests or insects, and about $13 \%$ for diseases [5]. The acceptance of transgenic technology is assured to reduce the reduction and productivity of standard and secure vegetables.

\subsubsection{Viral Resistance}

Virus-immune GE plants are exceptionally useful if no hereditary origin of immune has been recognized or if host immune is hard to pass on within noble cultivars by conservative propagation practice on account of hereditary conflict or connection with unacceptable features. In such example, to develop virus-resistant cultivars the transgenic application may be the single possible choice. Plants with virus-resistant are formed by two processes: the RNA silencing method and pass on the gene putting into code for protein coat of the virus, that block the duplication of virus. GE vegetables manipulated for the upgrade of TMV (tomato mosaic virus) coat protein (CP) gene were rebellious to TMV infection and this CP-moderate immune is extensively cast-off to secure several crops from a huge number of viruses [7]. James, 1998 reported the major country to make sellable virus-immune GM crops was China and eventually, virus-immune potato, tomato, watermelon, and squash plants were matured $[8,9]$. GE potato immune versus potato virus $\mathrm{Y}$ which blocks replication of the virus was improved by Monsanto via error of the gene arranging for viral CP. Closely, transgenic tomato and cucumber varieties were improved by transferring viral $\mathrm{CP}$ which was resistant to cucumber mosaic virus (Table 1). Transgenic common bean immune in opposition to bean golden mosaic virus was improved by the RNA silencing method.

Table 1. Vegetables engineered against viruses

\begin{tabular}{ccccc}
\hline Virus & Origin of transgene & Transgenic output & Transformed Plant & Reference \\
\hline TYLCV & TYLCV & Viral coat protein & Tomato & Kuniket al. 1994 \\
& TYLCV & Cl-gene & Tomato & Brunetti et al.1997 \\
TSWV & TSWV & N-gene & Tomato & Pang et al. 1992 \\
Tomato Mosaic Virus & ToMV & Anti sense RNA & Tomato & Beachy et al. 1997 \\
Cucumber Mosaic Virus & CMV & Satellite RNA & Tomato & Sotmmel et al.1998 \\
Potato Virus X & PVX & Viral Coat protein & Potato & Homenway et al.1988 \\
Potato Virus Y & PVY & Viral Coat protein & Potato Kufri Jyothi & CPRI, Shimla \\
Cucumber Mosaic Virus & CMV & Viral Coat protein & Cucumber & Gonsalves et al. 1992 \\
\hline
\end{tabular}




\subsubsection{Fungal Resistance}

New approach of governing fungal infections enables through Genetic engineering. To establish genes arranging for the hydrolytic enzymes (glucanase/chitinase), initiating plant genes (proteinase inhibitors or phytoalexins) to increase inherent plant protection process, and implore a hypersensitive reaction within that contaminated single cells rapidly pass away at the place of fungal contamination also thus control their growth, Several transgenic approaches used (Table 2).

Table 2. Resistance genes against various fungal diseases

\begin{tabular}{ccc}
\hline Casual organism & $\begin{array}{c}\text { Gene } \\
\text { Transferred }\end{array}$ & Disease \\
\hline Alternaria brassicae & Thionin & Leaf spot \\
Fusarium oxysporum & RIP & Cabbage yellows \\
Perenosporaparasitica & Chitinase & Downy mildew \\
Rhizoctiniasolani & Glucanase & Wire stem \\
Phythiumspp. & Permatins & Damping off \\
Xanthomonas compestris & Chitinase & Black rot \\
Erwinia caratovora & Chitinase & Soft rot \\
Albugo candida & Osmotin & White rust \\
\hline
\end{tabular}

\subsubsection{Bacterial Resistance}

GE plants immune versus bacterial contamination are formed due to the relocation of antibacterial proteins like lysozymes, lytic peptides as well as iron-sequestering glycoproteins. Lytic peptides whose result is to create openings in bacterial membranes (e.g., attacin, cecropins etc.) are minor proteins including amphipathic $\alpha$-helical structure. Anzai et al., 1989 reported tobacco was the initial bacterial disease-immune plant immune in contrast to $P$ syringaepv. tabaci. and Pseudomonas syringaepv. In potato upregulation of an endochitinase gene with a tough gene promoter came off as developed immune against fungal ambushes. The plants showed developed immune to the soil borne pathogenic fungal and foliar [10] (Table $3)$.

Table 3. Resistance genes against various bacterial diseases

\begin{tabular}{|c|c|c|c|}
\hline Crop & $\begin{array}{l}\text { Origin of } \\
\text { transgene }\end{array}$ & $\begin{array}{c}\text { Resistance } \\
\text { against } \\
\text { Bacteria } \\
\end{array}$ & $\begin{array}{c}\text { Transgenic } \\
\text { output }\end{array}$ \\
\hline Potato & $\begin{array}{c}\text { Erwinia } \\
\text { caratovora }\end{array}$ & $\begin{array}{c}\text { Erwinia } \\
\text { caratovora }\end{array}$ & Pestate lyase \\
\hline Potato & $\begin{array}{l}\text { Aspergillus } \\
\text { niger }\end{array}$ & $\begin{array}{c}\text { Erwinia } \\
\text { caratovora }\end{array}$ & $\begin{array}{l}\text { Glucose } \\
\text { oxidase }\end{array}$ \\
\hline Potato & $\begin{array}{c}\mathrm{T} 4 \\
\text { bacteriophase }\end{array}$ & $\begin{array}{c}\text { Erwinia } \\
\text { caratovora }\end{array}$ & Lysozyme \\
\hline Potato & Horseshoe crab & $\begin{array}{c}\text { Erwinia } \\
\text { caratovora }\end{array}$ & Tachypelsin \\
\hline Bean & $\begin{array}{c}\text { Pseudomonas } \\
\text { syringae var } \\
\text { phaseocola }\end{array}$ & $\begin{array}{c}\text { Pseudomonas } \\
\text { syringae var } \\
\text { phaseocola }\end{array}$ & $\begin{array}{c}\text { Phaselotoxin } \\
\text { insensitive } \\
\text { OCTase } \\
\end{array}$ \\
\hline
\end{tabular}

\subsubsection{Insect Resistance}

In comparison with their progenitors, high-performance varieties are shown clearly less immune to pests. Insects kill about $25 \%$ of food crops globally in each year. Resist of pests, progress of immune, and matter of residuary toxicity are the result of the origination of plant monocultures with random as well as general use of chemical pesticides. To control this complication, progress of immune crop groups by a GM method will provide to a limiting in pest attack in addition to reduce the application of chemical pesticides [11].

The growth of Bacillus thuringiensis (Bt) insect-immune crops applying plant GM method is the greatest achievement in the field of agriculture. Bttoxin is a translucent insecticidal protein ( $\delta$-endotoxin) generated out of cryo gene of a spore-making soil bacterium $B$. thuringiensis. This is a powerful insecticide also extremely poisonous to dipterans [11], lepidopterans [12], and coleopterans [13]. Btcry protein is safe to humans plus animals, however harmful to insects (BANR). In 1981 the main Bttoxin gene was duplicated $[14,15]$ and a field experiment of GM tobacco showing Bttoxin was executed in 1986. GE eggplant/brinjal and tomato were matured subsequently and checked beneath field situation in various countries. A fusion of vast transgene expression and enhanced protein strength developed in fatality of uniform $B t$-immune insects [16]. Now a days, more insecticidal proteins like antibodies, lectins, protease inhibitors, microbial insecticides, wasp, spider toxins, with insect peptide hormones $[17,18,19]$ were profitably cast-off for the growth of insect-immune vegetable crops. Bt eggplant (Solanum melongena) was progressed and field evaluated by the joint investigation within the US-based company Monsanto along with Maharashtra Hybrid Seeds Company (Mahyco), India, by including a crystal gene (Cry1Ac) from B. thuringiensis [20, 21, 22].

Serine proteinases like trypsin as well as chymotrypsin enzymes are available within insect guts for ingestion. Proteinase inhibitors have been established more effectual in managing the development and growth of several insects by deactivation of serine proteinase enzymes of the insect. In crop plants several groups of proteinase inhibitors like potato protease inhibitors II, cowpea trypsin inhibitors (CpTi), etc. have been showed [23]. Numerous insect-immune plant groups have been flourished by cloning genes encoding proteinase inhibitors as well as amylase inhibitors [24, 25] (Table 4 and Table 5). 
Table 4. Bt genes moved for insect immune in vegetables.

\begin{tabular}{|c|c|c|c|c|}
\hline Modified Plant & Transgene Organism & Selected insect & Transgenic output & References \\
\hline Brinjal & Bacillus thuringiensis & $\begin{array}{l}\text { Leptinotarsa } \\
\text { decimlineata }\end{array}$ & Cry $3 A$ & Jelenkovic et al.1998 \\
\hline Cabbage & Bacillus thuringiensis & DBM Plutellaxylostella & Cry $1 A$ & Sharma 1999 \\
\hline Cabbage & Bacillus thuringiensis & $\begin{array}{c}\text { Butterfly } \\
\text { Pieriesbrassicae }\end{array}$ & Cry $1 A$ & Sharma 1999 \\
\hline Tomato & Bacillus thuringiensis & Helicoverpaarmigera & Cry $1 A B$ & Kumar et al.1998 \\
\hline Corn & Bacillus thuringiensis & Helicoverpaarmigera & Cry $1 H$ & Duck et al.1997 \\
\hline
\end{tabular}

Table 5. Various plant anti nutritional factors act in opposition to insect pest.

\begin{tabular}{|c|c|c|c|c|}
\hline Transformed plant & Organism of transgene & Target insect & GM product & References \\
\hline Tomato & Snowdrop & Lepidoptera & Snowdrop lectin $(G N A)$ & $\begin{array}{c}\text { Gatehouse et al. } \\
1992\end{array}$ \\
\hline Tomato & Cowpea & $\begin{array}{l}\text { Coleoptera } \\
\text { Lepidoptera }\end{array}$ & $C p T$ (Cowpea Trypsin Inhibitor) & $\begin{array}{c}\text { Gatehouse et al. } \\
1992\end{array}$ \\
\hline Tomato & Tomato & Lepidoptera & Tomato protease inhibitor I \& II & Mc Gurl et al 1994 \\
\hline Potato & Pea & Aphid & Pea lectin & \\
\hline Pea,Potato,Common bean & Common bean & Coleoptera & Alpha amylase inhibitor & $\begin{array}{c}\text { Scgroeder et al } \\
1995\end{array}$ \\
\hline Lettuce & Bovine & Lepidoptera & $\begin{array}{l}\text { Bovine pancreatic trypsin } \\
\text { inhibitor }\end{array}$ & Schuler et al 1998 \\
\hline
\end{tabular}

Table 6. Designing for herbicide tolerance

\begin{tabular}{|c|c|c|c|c|}
\hline Origin & Transferred plant & Resistant to herbicide & Transgene & $\begin{array}{l}\text { Ground of } \\
\text { resistance }\end{array}$ \\
\hline Klebsiella pneumoniae & Tomato & Bromoxynil & bxn(nitrilase) & $\begin{array}{c}\text { Detoxification of } \\
\text { herbicide }\end{array}$ \\
\hline & Tomato & Atrazine & Glutathione-S-transferase & $\begin{array}{l}\text { Detoxification of } \\
\text { herbicide }\end{array}$ \\
\hline Streptomyces spp. & Tomato, Sugarbeet & L- phosphinothricin & $\begin{array}{c}\text { bar (phosphinothricin } \\
\text { acetyl transferase) }\end{array}$ & $\begin{array}{c}\text { Detoxification of } \\
\text { herbicide }\end{array}$ \\
\hline
\end{tabular}

Lectins, the carbohydrate-binding proteins, take place richly in the seeds including tissues storing of separate plants and were also found to be harmful to the distinct pests however not to the mammals [26]. The snowdrop (Galanthus nivalis agglutinin) lectin is extremely harmful to the insects, creating fatalities around $80 \%$ [27]. Transgenic potato effect in the gangrene revealed lessens injury to leaves [28]. A Bttransgenic potato plant rebellious to potato tuber moth was succeeded by moving the cry $1 \mathrm{Ab}$ gene to the bottom of a granule-bound starch synthase promoter [29]. In 2009, Bteggplant was accepted for commercial purpose in India, however the Indian government pursues to introduce a moratorium on its deliver as of public dissatisfaction [15].

\subsubsection{Herbicide Resistance}

$71 \%$ of the total GM crops are globally advanced with herbicide-immune Genetically Modified plants [4]. Three techniques have been cast-off to produce herbicide-immune crops: organizational adjustment of the selected enzyme because plant susceptibility to the herbicide is suppressed set-up of the herbicide-detoxifying passageway inside the plant, as well as excessive production of an herbicide-susceptible biochemical objective [30]. Gaines et al., 2010 succeed herbicide-immune Amaranthus palmer through showing glyphosate-unresponsive herbicide select region gene, EPSPS (5-enolpyruvylshikimate- 3-phosphate synthase) that is elaborated within the shikimate pathway. 5-enolpyruvylshikimate- 3-phosphate synthase encoding gene has been moved inside plants as well as gives out to the plants combined along herbicide immunethrough detoxification, for example herbicide Basta/Ignite is the restricting immune gene against Streptomyces hygroscopicus cast-off to remove poison from herbicide; several GM plants showing the bar or restricting gene were created in addition to tomato, potato, and sugar beet [31] (Table 6). 


\subsubsection{Transgenic Approach for Abiotic Stress Management}

The natural situation that minimizes crop development also output under ideal proportion is known as abiotic stress. That comprises heat, salinity, cold, drought, metal toxicity as well as nutrient insufficiency. As evaluated, more than 50\% output of the crop plants are dwindled due to the abiotic stress. As the intertwined occurs a usual phenomenon in plants, which results in cellular water loss known as osmotic stress which causes maximum abiotic stresses. Due to the osmotic stress, osmolite (low molecular weight compounds) an alternatively osmoprotectant is produced by the crops or plants. The osmotic potential is reduced by the above-mentioned molecules which continue turgor in the cells. As various processes of transgenic methods engaged for enhancing the immune constrain in plants are the initiation of enzymes encoded by the genes which activate the altering of a normally occurring substrate into a product for osmoprotective belongings and radical-scavenging enzymes, the initiation of genes coding membrane-altering enzymes, or stress-generated proteins [32]. Increased abiotic stress immune was performed by the upregulation of the gene (d-galacturonic acid reductase) in strawberry gene to potato that managed the quantity of vitamin $\mathrm{C}$ along increased resistance of abiotic stress. Hmida-Sayariet al. [33] described the upregulation of the gene ( $\Delta 1$-pyrroline-5-carboxylate synthetase) in GM potato plants gives resistance against salt tolerance. Likewise, modification of the tomato along the BADH gene derived out of Atriplex revealed a significant amount of salt resistance [34].

A unique gene likely to give drought tolerance, cloned from a drought tolerant land race of sorghum M-35-1, was used for transformation of tomato. Average number of fruits and average yield per plant was higher than control varieties. In network project on transgenic crops at IIVR (NPTC), water-deficit stress tolerant transgenic tomato was developed using AtDREB1A gene. Another BcZAT12 transformed tomato line was useful for improving its quality in heat, drought or salt stressed conditions (Source Annual report IIVR 2012-13 and 2013-14).

The salt stress exposed transgenic tomato plants recorded:

- Higher relative water content

- Lower membrane damage indicated by lower electrolyte leakage and lipid peroxidation (MDA) in compared to the non-transgenic (WT) plants.

Over-expression of rd29A:AtDREB1A/CBF3 imparted lower susceptibility to salt stress (IIVR Annual Report 2014-15).

In carrot heat shock, protein coding gene HSP17.7 is established whichever moved to further species for creating thermal stress [35]. The winter flounder fish Anti freezing protein gene has been incorporated into tomato and soya bean to resist against freezing cold [36] (Table 7).

\subsubsection{Engineering for Male infertility}

For economic hybrid seed making male sterility is a tool. In crops such as Okra, where male sterility hasn't been seen in cultivated along with wild relatives, we may move it from micro organisms by utilizing R-DNA method. It is so far cast-off in Tomato and Brassicas.

\subsubsection{Designing for Nutrition and Quality}

Grain Amaranthus is a hypochondriac's carrying excessive storage grain protein content. The present protein consists of 2-4 folds extra essential amino acids Lysine, Threonine, Leucine, \& Methioninethan the usual ones.AmAl gene accountable for long storage has been moved well to Potato [37].

During chips making out of Potato var. carbonize of sugar occurs with maximum sugar content in potatoes. The food industry requires the Potato varieties enriched with more starch content. The initial enzyme in the pathway of starch biosynthesis is ADPGPP- ADP Glucose Pyro Phosphorylas. This gene has been moved from E.coli to potato cultivars that derived in considerable rise in starch content in potato tubers (Monsanto, USA).

Table 7. Designing for post harvest traits

\begin{tabular}{ccccc}
\hline Modified plant & Reason & Source of transgene & Transgene output & References \\
\hline Tomato & Enhance shelf life & Tomato & Antisense & Sheehy et al.1988 \\
Tomato & Fruit coloration & Tomato & Phtoene synthase gene & Bird et al. 1991 \\
Tomato & Inhibition of ripening & Tomato & Antisense ACC synthase & Oeller et al. 1991 \\
Tomato & Tomato & Antisense ACC oxidase & Hamilton et al. 1990 \\
\hline
\end{tabular}




\subsubsection{Molecular Markers}

The polymorphic level of DNA is directly disclosed through molecular markersand utilized in creation of genetic linkages well as high-resolution genetic maps within markers and for vegetable breeding improvement that has been exploited as important crop attribute [38,39]. In order to identify the cultivars or varieties of vegetable such as in potato [40], tomato [41], ginger [42, 43, 44], onion, garlic, and related species [45] (Table 8, Table 9, Table 10) etc. the technique of marker have been employed. Diversified range of molecular markers such as SNP, EST, SSR, AFLP, RAPD, RFLP etc. are used for evolutionary and phylogeny studies; growth of saturated hereditary maps; and; DNA fingerprinting; marker assisted selection (MAS); heterotic breeding; and gene tagging.

Table 8. Marker-applications in breeding of potato

\begin{tabular}{|c|c|c|c|c|}
\hline Breeding aim & Kind of marker & Breeding Plan & Type of breeding aim & References \\
\hline $\begin{array}{l}\text { Wide scope potato late blight } \\
\text { immune derived from Solanum } \\
\text { bulbocastanum }\end{array}$ & PCR marker & $\begin{array}{l}\text { Introgression; } \\
\text { MABC }\end{array}$ & Diseases/pest resistance & Colton et al.2006 \\
\hline $\begin{array}{l}\text { Fusion of immune to potato virus } \\
\mathrm{Y} \text {, root cyst nematode, potato } \\
\text { virus } \mathrm{X} \text {, and potato wart }\end{array}$ & $\begin{array}{c}\text { CAPS,SCAR PCR } \\
\text { based markers }\end{array}$ & Pyramiding & Diseases/ pest resistance & Gebhardt et al.2006 \\
\hline Potato virus $\mathrm{Y}$ immune & PCR marker & MAS & pest resistance & Fulladolsa et al.2015 \\
\hline
\end{tabular}

Table 9. Marker-applications in breeding of Tomato

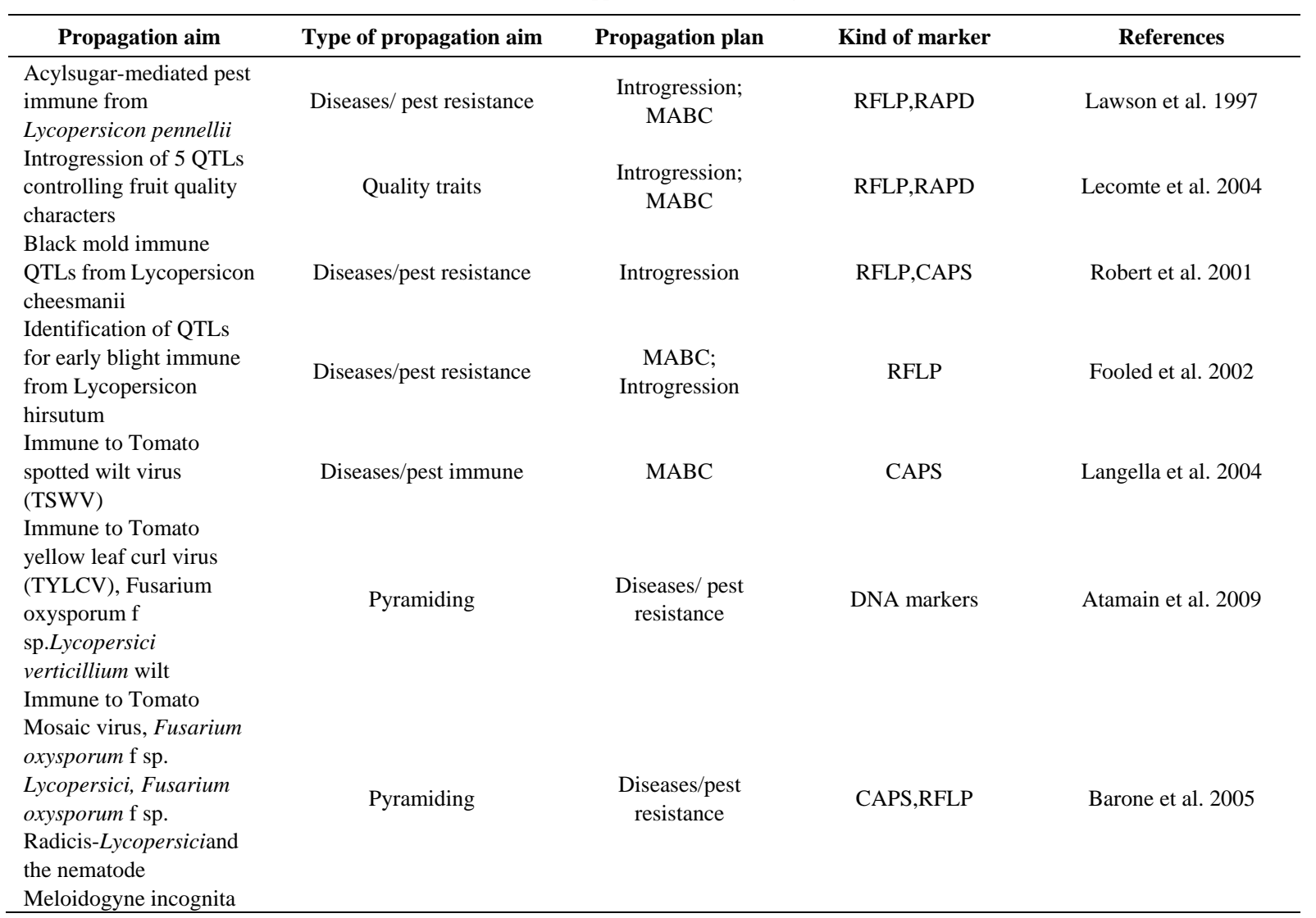


Table 10. Marker-applications in other vegetables breeding

\begin{tabular}{|c|c|c|c|c|c|}
\hline \multicolumn{2}{|c|}{ Breeding aim } & Type of breeding aim & Breeding plan & kind of marker & References \\
\hline \multicolumn{2}{|c|}{$\begin{array}{l}\text { Introgression of } 4 \text { Phytophthora capsici } \\
\text { immune QTLs into bell pepper }\end{array}$} & Diseases/pest immune & Introgression; MABC & $\begin{array}{l}\text { RAPD, SCAR, } \\
\text { CAPS, RFLP, } \\
\text { AFLP and ISSR }\end{array}$ & $\begin{array}{l}\text { Thabuis et al. } \\
2004\end{array}$ \\
\hline $\begin{array}{l}\text { Immune to L } \\
\text { Colletotrich } \\
\text { vulgaris }\end{array}$ & $\begin{array}{l}\text { appendiculatus and } \\
\text { uthianum in Phaseolus }\end{array}$ & Diseases/pest immune & MABC & RAPD & $\begin{array}{l}\text { Faleiro et al. } \\
\quad 2004\end{array}$ \\
\hline $\begin{array}{l}\text { Immune to } \mathrm{C} \\
\text { in P.vulgaris }\end{array}$ & um lindemuthianum & Diseases/pest immune & MABC & SCAR & $\begin{array}{l}\text { Miklasetal. } \\
\quad 2003\end{array}$ \\
\hline $\begin{array}{l}\text { Common ba } \\
\text { kidney bean }\end{array}$ & ht immune in dark red & Diseases/pest immune & MABC & SCAR & $\begin{array}{l}\text { Miklasetal. } \\
\quad 2003\end{array}$ \\
\hline $\begin{array}{l}\text { Enhanced in } \\
\text { SCAR in be }\end{array}$ & ommon bacterial wilt & Diseases/pest immune & MABC & SCAR & $\begin{array}{l}\text { Mutlu et al. } \\
\quad 2005\end{array}$ \\
\hline $\begin{array}{l}\text { Immune to } \\
\text { U.appendicu } \\
\text { Phaeoisariop } \\
\text { 'perola'(P.vl }\end{array}$ & $\begin{array}{l}\text { demuthianum and } \\
\text { in to cultivar }\end{array}$ & Diseases/pest immune & Pyramiding & $\begin{array}{l}\text { RAPD,SCAR } \\
\text { and SSR }\end{array}$ & $\begin{array}{l}\text { Ragagnin et al. } \\
2003\end{array}$ \\
\hline $\begin{array}{l}\text { Immune to } \mathrm{r} \\
\text { necrosis viru }\end{array}$ & $\begin{array}{l}\text { ommon mosaic } \\
\text { V) in P.vulgaris }\end{array}$ & Diseases/pest immune & Selection & RAPD & $\begin{array}{l}\text { Beaver et al. } \\
\quad 1998\end{array}$ \\
\hline $\begin{array}{l}\text { Immune to b } \\
\text { (BGYMV) a } \\
\text { blight immu }\end{array}$ & $\begin{array}{l}\text { yellow mosaic virus } \\
\text { or common bacterial }\end{array}$ & Diseases/pest immune & Selection & SCAR & $\begin{array}{l}\text { Beaver et al. } \\
\quad 2008\end{array}$ \\
\hline S.N. & Crop & $\begin{array}{c}\text { gene prediction } \\
\text { number }\end{array}$ & Haplod chr.no. & $\begin{array}{l}\text { Approximated } \\
\text { enome size (Mb) }\end{array}$ & References \\
\hline 1 & Cucumber & 26,682 & 7 & 367.00 & Huang et al. (2009) \\
\hline 2 & Musk melon & 27,427 & 12 & 450.00 & $\begin{array}{c}\text { Gonzalez et al. } \\
\text { (2010) }\end{array}$ \\
\hline 3 & Potato & 39,031 & 12 & 844.00 & $\begin{array}{l}\text { The potato genome } \\
\text { sequencing } \\
\text { consortium (2011) }\end{array}$ \\
\hline 4 & Chinese cabbage & 41,174 & 10 & 529.00 & $\begin{array}{c}\text { The Brassica rapa } \\
\text { genome sequencing } \\
\text { project consortium } \\
(2011)\end{array}$ \\
\hline 5 & Tomato & 34,727 & 12 & 900.00 & $\begin{array}{l}\text { The tomato genome } \\
\text { consortium (2012) }\end{array}$ \\
\hline 6 & Water melon & 23,440 & 11 & 425.00 & Gau et al. (2013) \\
\hline 7 & Brinjal & 85,446 & 12 & 1126.00 & $\begin{array}{l}\text { Hirakawa et al. } \\
\text { (2014) }\end{array}$ \\
\hline 8 & French bean & 27,197 & 11 & 587.00 & $\begin{array}{l}\text { Schmutz et al. } \\
\text { (2014) }\end{array}$ \\
\hline 9 & Chilli & 34,903 & 12 & 3480.00 & Kim et al.(2014) \\
\hline 10 & Cabbage & 45,758 & 9 & 630.00 & Liu et al. (2014) \\
\hline 11 & Pumpkin & - & 20 & 271.4 & Zhang et al. (2015) \\
\hline 12 & Carrot & 32,113 & 9 & 473 & $\begin{array}{l}\text { Lorizzo et al. } \\
\text { (2016) }\end{array}$ \\
\hline
\end{tabular}

\subsubsection{Genome Sequencing}

Next generation sequencing helps crop improvement to progress lots of novel markers, also the discovery of agronomically major genes [46]. It allowed the development of high-density genetic maps. The sequence data obtained will help to identify the genes determining different traits. These data enable the unravelling of the regulatory mechanisms supporting different traits, and help to isolate the complete pathway. There are some limitations like huge genome size. Polyploidy revealed by various vegetable crop species (Table 11) hampered the sequencing and extra analysis. A more ratio of replicate elements is also a big obstacle in genome building. Other dare is that the functions of various genes recognized by genome sequencing persist unrevealed and the hereditary power of the majority of agricultural attributes has yet to be resolved.

Organized drilling and application of these data must be used to mature varieties with greater productivity and tolerance to biotic in addition to abiotic stresses and must help the wealth of tropical countries like India. 


\subsubsection{Tissue Culture}

The regeneration from a disease-free part of plants in a laboratory condition or in-vitro condition to a complete full-grown plant is referred as tissue culture. Micro-propagation is a technique of tissue culture which benefits in production of plant the clones. Examples of tissue cultured crops products include mangoes, bananas, coffee, papayas, citrus, avocados and pineapples

\subsubsection{Meristem explants culture}

In meristem explants culture, somatic meristematic tissues are used as explants to get genetically true to type plants. In various vegetables like onion, shallot, pea, brinjal meristem culture were achieved (Table 12).

Table 12. Success of meristem explants culture in many vegetables.

\begin{tabular}{|c|c|c|}
\hline Crop & Reference & Purpose \\
\hline Brinjal & Raj et al.1991 & $\begin{array}{l}\text { Elimination of } \\
\text { mosaic virus }\end{array}$ \\
\hline Onion & Walkey et al.1987 & $\begin{array}{l}\text { Rejection of onion } \\
\text { yellow dwarf virus }\end{array}$ \\
\hline Pea & $\begin{array}{c}\text { Kartha and } \\
\text { Gamborg } 1978\end{array}$ & $\begin{array}{l}\text { Rejection of pea seed } \\
\text { borne mosaic virus }\end{array}$ \\
\hline Shallot & Walkey et al.1987 & $\begin{array}{c}\text { Elimination of onion } \\
\text { yellow dwarf virus }\end{array}$ \\
\hline
\end{tabular}

\subsubsection{Anther culture}

In anther culture pollen used as explants. Growth of more numbers of haploid plants through anther culture saves cost and time. In anther culture by chromosome repeating through colchicine care or via extra diploid plants, in vitro culture, homozygous at all loci, might be achieved. Anther culture keeps away from lengthy generation inherent and collection following hybridization. Hybrid lines initiated through anther culture are acquired in a smaller period and display significant diversity than those acquired through self-pollination. Inbreedhomozygous lines with $100 \%$ obtained through anther culture in various vegetables like carrot, onion, cole crops. Successful selection is viable through anther culture as they carry extra component of variance only.

\subsubsection{Embryo rescue}

In embryo rescue immature embryo cast-off as explants. It is cast-off for control post fertilization obstacle (Embryo Abortion) in isolated hybridization.

\subsubsection{Cryo-preservation or Cryo-conservation}

Conservation of germplasm was a challenging task for farmers and agriculturists, biotechnological approaches have played a promising role in the preservation process. The storage of germplasm at an ultralow temperature, especially at $-196^{\circ} \mathrm{C}$ using liquid nitrogen is one of the unique storage applications of biotechnology known as cryopreservation or cryo-conservation. The major prospect of this approach is the storage can be done with minimal risk for an indefinite period. The management and conservation of wild verities are possible through gene banking, germplasm banking, micro-propagation techniques, tissue and organ culture due to the development of cryopreservation which has started new alterations in the hereditary and reintroduction of the recent and wild population reported by Schemske et al., [47].

\subsubsection{Somatic Hybridization}

The outcome of the combination of the two somatic cells of unlike species, genera or family is studied as somatic hybridization [48]. It is moreover accepted as Para sexual hybridization or Protoplast fusion. It is used to make Cybrids and Somatic Hybrids. It is cast-off to control pre fertilization obstacle in isolated hybridization. Feasible to change of cytoplasmic organelles such as chloroplast, mitochondria. E.g. mt of R.sativus and cp of B.compestris have been moved to B.oleracea to make use of organelle heterosis for productivity [49].

\subsubsection{Soma clonal Variations}

The generation of significant diversity, that is genetic through tissue culture is termed as SCV [48]. Diversity might be generated for: excessive productivity, Gene amplification (Some Herbicide rsst), Chromosome rearrangements, Herbicide immune, Fungal toxin immune, Temperature tolerance, Salinity tolerance, Chromosome structural changes (duplications, deletions), Gene mutations, Plasmid gene mutations (Streptomycin rsst mutation in cp DNA).

\subsubsection{Synthetic Seeds}

Synthetic seeds are enclosing somatic embryo that practically mimic seeds moreover might mature into seedlings beneath appropriate circumstances. In wide sense; this mention to enclose buds, bulbs all kinds of meristem that might grow into plantlets. The above mentioned are related to seeds [49]. The potentialities of synthetic seeds are

- Straight transfer of tissue cultured plants to the field to keep away from difficult and tedious impression of transplantations.

- Multiplication of useful genotypes with hereditary stability (Exceptional hybrids might be proliferated by tissue culture and generated by synthetic seeds).

- Limiting at the expense of vegetatively propagated noble plants.

- Successful controlling of fine somatic embryos or additional in vitro propagules.

- Conservation of existing germplasm also comfort in germplasm interchange.

There are various encapsulation agents like Agar, Sodium pectate, sodium alginate, sodium alginate with gelatin, Carboxy methyl cellulose, potassium alginate, Guar gum. Good encapsulation agents have some properties like 
1. Take part in the role of artificial endosperm and show physical protection

2. Safe to propagule

3. Grant proper growth and development of embryo

Thereafter coating this is required to include nutrients, fungicides also pesticides to increase the durability of sheath. Ogunwolu and Idowu crushed root bark as well as seed extract of neem for managing the insects also examined this can be option for insecticides [50].

\section{Advantages for Improving Vegetable Breeding and Production through Plant Biotechnology}

\subsection{Security and Future Prospect}

Food security is an upcoming global challenge, so in order to overcome such challenges the agriculture advancements resulted in drought tolerance and disease resistance by sustainable agronomic crop's trait improvement. Recent agricultural practices ensure food security due to substantial production at an economical price. The edible plants nutritional value's amelioration, phytoremediation, production of biofuel, hirudin (anti-thrombin protein) a therapeutic protein produced by plant and medicinal application of plant-based compounds are the additional utility of the plants. The expansion in the field of plant breeding has culminated with many new inventions and novel innovations resulting in an abundant number of patents for future commercialization in the field of agriculture which can build a foundation for agriculturally based industries [51]. The upgraded technologies like DNA chips and microarrays have made gene expression study more feasible due to which the improvement the quality and quantity of vegetable crops as easier and faster [52] (Figure 2).

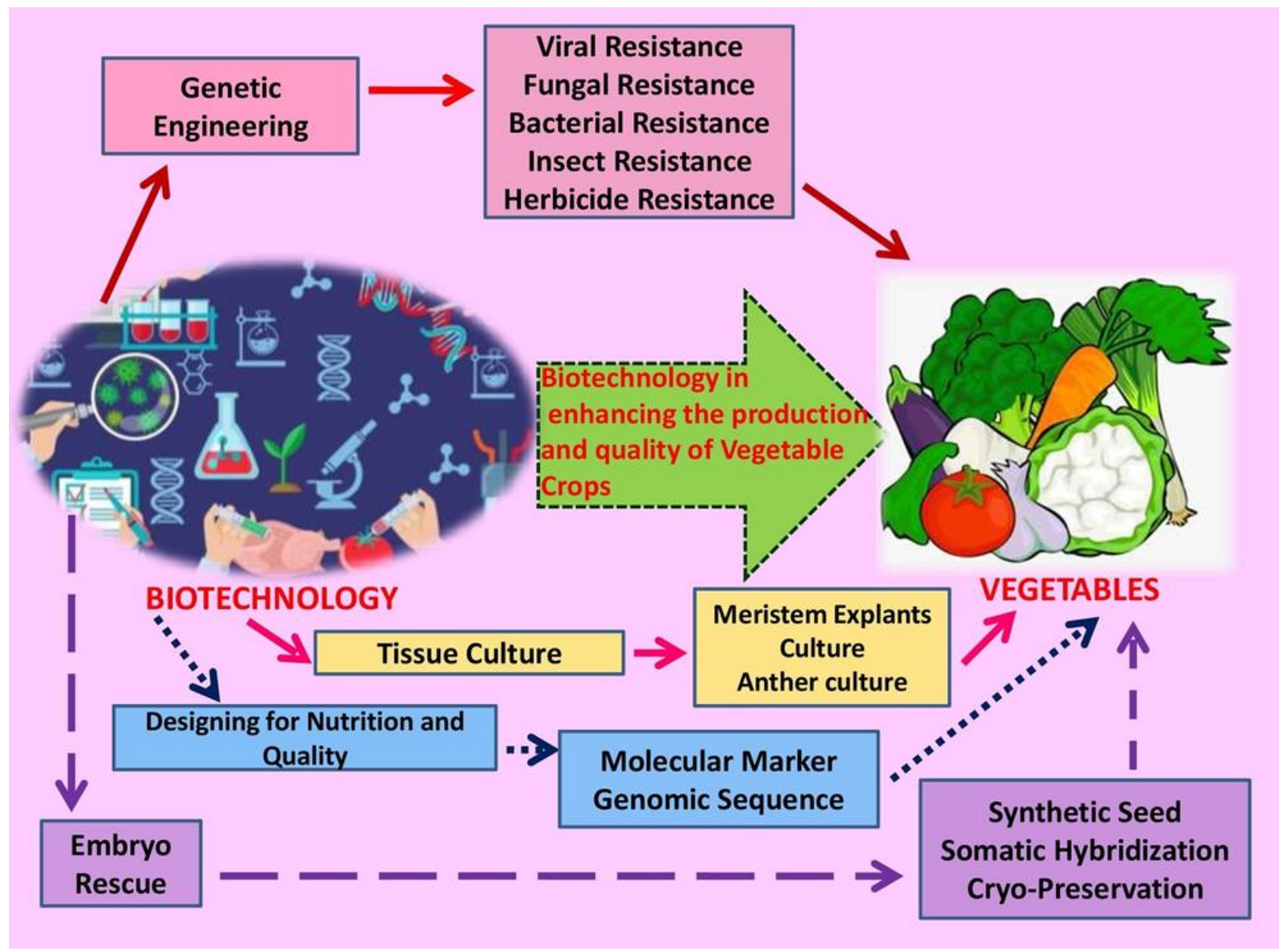

Figure 2. Improving the quality and quantity of vegetables for future food security 


\subsection{Limitations}

The food nutritional values get altered in an unpredictable manner by foreign genes as reports suggest. The microbial based engineered foods are known to have allergenic prospective due to ignorance or lack of proper experimental test. As the major part of the GM Crops is developed through microbial based gene transfer, there is a chance for transfer of allergen property. The plants have possibilities for cross pollination, as the GM crops are pest and herbicide resistant with the gene of wild species, the cross pollination with weeds may result in super weeds.

The global marketing of transgenic crops and modern agricultural practices can be a threat to endangered crop genetic diversity which may result in conservation of few crops varieties only. The agriculturist claims commercialization of GM crops may create a monopoly marketing control by the investors and inventors through their patent polices. There is despair among the organic farmers that it would be quite difficult after some days to differentiate between GM and non-GM crops as GM crops are untagged or without labelled.

\section{Conclusion}

The above review concludes with an emphasis on the revolution in the field of biotechnology that highlights advancement of horticulture science, which is accomplished with superior quality and higher productivity of vegetable crops. Such interdisciplinary subject depends upon proficiency in proteomics, transcriptomics and genomics, a substantial knowledge in plant biology, a solid qualification in statistical software analysis, expertise in functional genomics as well as molecular biology laboratory techniques with experience in field-based breeding and should be potentially capable of handling extensive and diverse set of data. In order to achieve the rapid growth in the field of vegetable and food Science there is a need for translation of knowledge into pragmatic application by the plant biotechnologists to benefits the consumer directly.

\section{REFERENCES}

[1] Mathur AK., Ahuja PS., Pandey B., Kukreja AK., Mandal S. "Screening and evaluation of somaclonal variations for quantitative and qualitative traits in an aromatic grass, Cymbopogon winterianusJowitt." Plant Breeding. Vol.101. no.4. pp.321-34, 1988.

[2] Nayak S., Debata BK., Srivastava VK., Sangwan NS. "Evaluation of agronomically useful somaclonal variants in Jamrosa (a hybrid Cymbopogon) and detection of genetic changes through RAPD." Plant Science. vol. 164. no.6. pp.1029-35, 2003.

[3] Tengerdy RP., Szakács G. "Perspectives in agrobiotechnology. Journal of biotechnology." vol.66. no.2-3. pp.91-9, 1998.

[4] James C. "Global status of commercialized biotech/GM crops". Ithaca, NY: isaaa; 2011 Feb 22.

[5] Pimentel D. "Techniques for reducing pesticide use: economic and environmental benefits." John Wiley and Sons; 1997.

[6] Meeusen, RL.. "Commercialization of transgenic seed products: two case studies. "In: Collins, GB., Shepherd, R.J. (Eds.), Engineering Plants for Commercial Products and Applications. New York Academy of Sciences, 1996, pp. 172-176.

[7] Oerke EC. "Crop losses to pests." The Journal of Agricultural Science. vol. 144. no.1. pp.31-43, 2006.

[8] Mundembe R., Matibiri A., Sithole-Niang I. "Transgenic plants expressing the coat protein gene of cowpea aphid-borne mosaic potyvirus predominantly convey the delayed symptom development phenotype." African Journal of Biotechnology.vol.8. no.12. pp.2682-90, 2009.

[9] James C. "Global review of commercialized transgenic crops”. Ithaca, NY: Isaaa; 1998.

[10] Anzai H., Yoneyama K., Yamaguchi I. "Transgenic tobacco resistant to a bacterial disease by the detoxification of a pathogenic toxin." Molecular and General Genetics MGG. vol. 219. no.3. pp.492-4, 1989.

[11] Slater A., Scott N., Fowler M.N.W.Scot.t, M.R. Fowler (Eds.).. "Plant Biotechnology", the Genetic Manipulation of Plants, first ed. Oxford University Press Inc., New York, USA. 2003, pp.346.

[12] Cohen MB., Gould F., Bentur JS. "Bt rice: practical steps to sustainable use.” International Rice Research Notes. vol.25. no.2. pp.4-10. 2000.

[13] Herrnstadt C., Soares GG., Wilcox ER., Edwards DL. "A new strain of Bacillus thuringiensis with activity against coleopteran insects.” Bio/technology. vol. 4(4). pp.305-8, 1986.

[14] Schnepf HE., Whiteley HR. "Cloning and expression of the Bacillus thuringiensis crystal protein gene in Escherichia coli." Proceedings of the National Academy of Sciences. vol.78. no.5. pp.2893-7, 1981.

[15] Jain M., Chengalrayan K., Abouzid A., Gallo M. "Prospecting the utility of a PMI/mannose selection system for the recovery of transgenic sugarcane (Saccharum spp. hybrid) plants.” Plant cell reports. vol.26. no.5. pp.581-90, 2007.

[16] Kota M., Daniell H., Varma S., Garczynski SF., Gould F., Moar WJ. "Overexpression of the Bacillus thuringiensis (Bt) Cry2Aa2 protein in chloroplasts confers resistance to plants against susceptible and Bt-resistant insects." Proceedings of the National Academy of Sciences. vol.96. no.5. pp.1840-5, 1999.

[17] Whetstone PA., Hammock BD. "Delivery methods for peptide and protein toxins in insect control. Toxicon." vol.49. no.4. pp.576-96, 2007. 
[18] Van Damme, EJM. "Plant lectins as part of the plant defense system against insects." In: Schaller, A. (Ed.), Induced Plant Resistance to Herbivory. Dordrecht. Springer, The Netherlands, 2008, pp.285-307.

[19] Mary L. Mhazo, Edna C. Kunjeku, Abraham Addo-Bediako, Barry W. Blair, "Evaluation of Aphicidal Effects of Solanum panduriforme Extracts on Cabbage Aphid Brevicoryne brassicae (Homoptera: Aphididae)," Universal Journal of Agricultural Research, Vol.9, No.1, pp.1-5, 2021. DOI: 10.13189/ujar.2021.090101.

[20] Krattiger A. "Intellectual property, commercial needs and humanitarian benefits: must there be a conflict?". New biotechnology. vol.27. no.5. pp.573-7, 2010.

[21] Cotter J. "Genetically engineered (GE) Bt eggplant (talong): Health risks, environmental impacts and contamination from field trials." Greenpeace Research Laboratories Technical Note 02/2011, February 2011 Greenpeace Research Laboratories, School of Biosciences, Innovation Centre Phase 2RennesDrive, University of Exeter, ExeterEX4 4RN, UK. http://www.greenpeace.to.

[22] Kar D., Kuanar A., Ray A., Gaur M., Pattanaik B., Mishra B. "Genetic Diversity of Brinjal Fruit and Shoot Borer (BSFB) Population of Odisha, India. " Iranian Journal of Science and Technology, Transactions A: Science. vol.45. no.1. pp.135-44, 2021.

[23] Sharma HC., Sharma KK., Crouch JH. "Genetic transformation of crops for insect resistance: potential and limitations." Critical Reviews in Plant Sciences. vol.23. no.1. pp.47-72, 2004.

[24] Kim JY., Park SC., Hwang I., Cheong H., Nah JW., Hahm KS., Park Y. "Protease inhibitors from plants with antimicrobial activity." International journal of molecular sciences. vol.10. no.6. pp.2860-72, 2009.

[25] Mehrabadi M., Bandani AR., Saadati F. "Inhibition of Sunn pest, Eurygasterintegriceps, $\alpha$-amylases by $\alpha$-amylase inhibitors (T- $\alpha \mathrm{AI})$ from Triticale. "Journal of Insect Science. Vol.10. no.1. pp.1-13, 2010.

[26] Li Y., Romeis J. "Impact of snowdrop lectin (Galanthus nivalis agglutinin; GNA) on adults of the green lacewing, Chrysoperlacarnea." Journal of insect physiology. vol.55. no.2. pp.136-43, 2009.

[27] Fitches EC., Bell HA., Powell ME, Back E, Sargiotti C., Weaver RJ., Gatehouse JA. "Insecticidal activity of scorpion toxin (ButaIT) and snowdrop lectin (GNA) containing fusion proteins towards pest species of different orders." Pest Management Science: formerly Pesticide Science. vol.66. no.1. pp.74-83, 2010.

[28] Bell HA., Fitches EC., Marris GC., Bell J., Edwards JP., Gatehouse JA., Gatehouse AM. "Transgenic GNA expressing potato plants augment the beneficial biocontrol of Lacanobia oleracea (Lepidoptera: Noctuidae) by the parasitoid Eulophus pennicornis (Hymenoptera; Eulophidae)." Transgenic Research. vol.10. no.1. pp.35-42, 2001.

[29] Kumar M., Chimote V., Singh R., Mishra GP., Naik PS., Pandey SK., Chakrabarti SK. "Development of Bt transgenic potatoes for effective control of potato tuber moth by using cry $1 \mathrm{Ab}$ gene regulated by GBSS promoter." Crop Protection. vol.29. no.2. pp.121-7, 2010.
[30] Simoens C., Van Montagu M. "Genetic engineering in plants." Human reproduction update. 1. vol.6. pp.523-42, 1999.

[31] Gaines TA., Zhang W., Wang D., Bukun B., Chisholm ST., Shaner DL., Nissen SJ., Patzoldt WL., Tranel PJ., Culpepper AS., Grey TL. "Gene amplification confers glyphosate resistance in Amaranthus palmeri." Proceedings of the National Academy of Sciences. vol.107. no.3. pp.1029-34, 2010.

[32] Holmberg N., Bülow L. "Improving stress tolerance in plants by gene transfer." Trends in plant science. vol.3. no.2. pp.61-6, 1998.

[33] Hmida-Sayari A., Gargouri-Bouzid R., Bidani A., Jaoua L., Savouré A., Jaoua S. "Overexpression of $\Delta 1$-pyrroline-5-carboxylate synthetase increases proline production and confers salt tolerance in transgenic potato plants." Plant Science. Vol.169. no.4.. pp.746-52, 2005.

[34] Jia GX., Zhu ZQ., Chang FQ., Li YX. "Transformation of tomato with the BADH gene from Atriplex improves salt tolerance.” Plant Cell Reports. vol.21. no.2. pp.141-6 2002.

[35] Malik MK., Slovin JP., Hwang CH., Zimmerman JL. "Modified expression of a carrot small heat shock protein gene, Hsp17. 7, results in increased or decreased thermotolerance.” The Plant Journal. vol.20. no.1. pp.89-99, 1999.

[36] Hightower R., Baden C., Penzes E., Lund P., Dunsmuir P. "Expression of antifreeze proteins in transgenic plants. “Plant molecular biology. vol.17. no.5. pp.1013-21, 1991.

[37] Chakraborty S., Chakraborty N., Datta A. "Increased nutritive value of transgenic potato by expressing a nonallergenic seed albumin gene from Amaranthus hypochondriacus." Proceedings of the National Academy of Sciences. vol.97. no.7. pp.3724-9, 2000.

[38] Edwards MD., Stuber CW., Wendel JF. "Molecular-marker-facilitated investigations of quantitative-trait loci in maize. I. Numbers, genomic distribution and types of gene action." Genetics. Vol.116. no.1. pp.113-25, 1987.

[39] Paterson AH., Lander ES., Hewitt JD., Peterson S., Lincoln SE., "Tanksley SD. Resolution of quantitative traits into Mendelian factors by using a complete linkage map of restriction fragment length polymorphisms." Nature. vol.335 no.6192. pp.721-6, 1988.

[40] Ashkenazi V., Chani E., Lavi U., Levy D., Hillel J., Veilleux RE. "Development of microsatellite markers in potato and their use in phylogenetic and fingerprinting analyses." Genome. vol.44. pp.50-62, 2001.

[41] Noli E., Conti S., Maccaferri M., Sanguineti MC. "Molecular characterization of tomato cultivars. "Seed Science and Technology. Vol.27.no.1. pp.1-10, 1999.

[42] Kar D., Pattanaik PK., Acharya L., Panda MK., Sathapathy K., Kuanar A., Mishra B. Assessment of genetic diversity among some elite cultivars of ginger (Zingiber officinale Rosc.) using isozyme and protein markers. Brazilian Journal of Botany. vol.37. no.4. pp.469-79. 2014.

[43] Pattnaik PK., Kar D., Kuanar A., Sahu A., Mishra B. "Molecular \& Biochemical characterization of selected elite accessions of ginger." Biocatalysis and Agricultural 
Biotechnology. vol.8, pp.130-8, 2016.

[44] Mohanty S., Parida R., Kuanar A., Sahoo S., Nayak S. Evaluation of genetic fidelity of in vitro propagated shampoo ginger (Zingiber zerumbet (L.) Smith) using DNA based markers. Journal of Medicinal Plants Research. vol6. no.16. pp.3143-7.2012.

[45] Fischer D., Bachmann K. "Onion microsatellites for germplasm analysis and their use in assessing intra-and interspecific relatedness within the subgenus Rhizirideum." Theoretical and Applied Genetics. vol.101. no.1. pp.153-64, 2000.

[46] Edwards D., Batley J. "Plant genome sequencing: applications for crop improvement. Plant biotechnology journal. vol.8. no.1. pp.2-9, 2010.

[47] Schemske DW, Husband BC, Ruckelshaus MH, Goodwillie C, Parker IM, Bishop JG. "Evaluating approaches to the conservation of rare and endangered plants. Ecology." vol.75. no.3. pp.585-606, 1994.
[48] Rai N., Rai M. "Heterosis breeding in vegetable crops." New India Publishing; 2006.

[49] Pelletier G., Primard C., Vedel F., Chetrit P., Remy R., Rousselle P., Renard M. "Intergeneric cytoplasmic hybridization in cruciferae by protoplast fusion [Brassica napus, Brassica campestris, Raphanus sativus]." In6. Congres international sur le colza, Paris (France), pp.17-19, 1983.

[50] Ogunwolu O. "Potential of powedred Zanthoxylum zanthoxyloides (Rutaceae) root bark and Azadirachta indica (Meliaceae) seed for control of the cowpea seed bruchid, Callosobruchus maculatus (Bruchidae) in Nigeria.” Journal of African zoology. vol.108. no.6. pp.521-8, 1994.

[51] Hefferon K. "Plant biotechnology patents: applications in agriculture and medicine." Recent patents on biotechnology. vol,42, pp.136-52, 2010.

[52] Schaffer R., Landgraf J., Pérez-Amador M., Wisman E. "Monitoring genome-wide expression in plants." Current opinion in Biotechnology. Vol.11. no.2. pp.162-7, 2000. 